\title{
DE ARRENDATARIOS A PROPIETARIOS. HISTORIA LEGALISTA DE LA PROPIEDAD AFORADA EN GALICIA
}

\author{
From tenants to owners. Legalistic background of property under \\ long-term leases in Galicia
}

\author{
Juan Montero FernándeZ \\ Seguridad Social. UNED
}

Recibido: $24 / 06 / 20$

Aceptado: 04/07/20

\begin{abstract}
Resumen
Las pequeñas propiedades y explotaciones agrícolas componen en Galicia un paisaje rural tradicional. Con características generales en sus antecedentes medievales análogas a las de otras zonas de la península ibérica y el occidente europeo; la formación de una clase media agraria de pequeños propietarios y explotadores directos, requirió aferrarse a toda costa a la tierra y se produjo a través de un lento proceso, cuyo núcleo principal vino determinado por la manera en la que el liberalismo español negoció con su pasado inmediato y desarrolló su modelo político y económico posterior. En el enfoque histórico de este trabajo hay una dominante jurídica, que viene dada por el legalismo adoptado en las soluciones y por ser la jurisprudencia la piedra de toque sobre la que se fue articulando el desarrollo de la cuestión de los foros y censos agrarios. Todo ello en relación con las circunstancias sociales, intenciones políticas y aspectos culturales de las que formó parte o intervinieron. En su consecuencia se presenta una versión periodizada en tres fases o momentos, del proceso
\end{abstract}

\begin{abstract}
Smallholdings and farms in Galicia make up a traditional rural landscape. With general characteristics in its medieval history similar to those that occurred in other areas of the lberian Peninsula and Western Europe; the formation of an agrarian middle class of small landowners and direct exploiters was the result of a slow process, whose main core was determined by the way in which Spanish liberalism negotiated with its immediate past and developed its subsequent political and economic model. In the historical focus of this work, there is a prevailing legal precept that derives from the legalism adopted and because jurisprudence is the touchstone on which the framework of the question of agricultural censuses and long-term leaseholds was developed. All this in relation to the social circumstances, political intentions and cultural aspects of which it was part or which intervened. Consequently, a version of periodization in three distinct phases comes to light, representing the process of consolidation of those properties that were exploited in the hands of the Galician pea-
\end{abstract}


de afianzamiento en manos de los campesinos gallegos de aquellas propiedades que explotaban, desde la paralización de los desahucios en 1763 hasta la consolidación de los dominios en el siglo XX. El periodo de referencia se inicia con la abolición de los señoríos en 1811 y termina con una norma definitiva en 1963. Efectuado a partir de las propuestas, debates, estudios jurídicos y textos legales sobre foros y censos, de finales del siglo XIX y comienzos del $\mathrm{XX}$, junto con fondos documentales privados y públicos, tanto familiares como de carácter judicial y económico. Asimismo, la perspectiva seńorial sobre la propiedad, sus derechos y concurrencias, se estudia de forma principal desde la visión de los escritos y propuestas del Marqués de Camarasa. Y en general, se ha contado con el valioso recurso historiográfico que suponen los importantes estudios sobre la materia.

\section{Palabras clave}

Foros; censos; laudemio; Galicia; desahucios; redención; consolidación. sants, from the stoppage of evictions in 1763 until the consolidation of property ownership in the twentieth century. The reference period begins with the abolition of jurisdictional lordships in 1811 and ends with a definitive rule in 1963. Undertaken in accordance with the proposals, debates, legal studies and legal texts on long-term leaseholds and censuses, from the late 19th and early 20th centuries, along with private and public documentation collections, whether family-owned or of a judicial and economic nature. Likewise, the perspective on property, its rights and concurrences of ownership, is studied mainly from the vision of the writings and proposals of the Marquis of Camarasa. On the whole, we have also relied on valuable historiographical resources offered by important studies on the subject.

\section{Key words}

Leaseholds; censuses; laudemium; Galicia; Spain; evictions; repossession; consolidation. 


\section{La pervivencia secular del régimen de propiedad. Permanencias tras los cambios, en la propiedad agraria}

\subsection{La conflictiva confusión entre foros y enfiteusis}

Relataba Eugenio Montero Ríos en el preámbulo del Proyecto de Ley de redención de censos y foros de $1886^{1}$, como sin ser una institución jurídica peculiar de Galicia, Asturias y León, las concesiones agrícolas a largo plazo de origen medieval sujetas a cargas, prestaciones y rentas; en esos reinos habían tomado un tinte local por circunstancias históricas, geográficas y culturales. Tal institución habría resultado más difundida que en otras regiones porque Iglesia y Monasterios habían adquirido grandes cantidades de tierras, hasta el extremo de asegurar que las siete novenas partes del reino de Galicia, en la plenitud medieval, pertenecían a abadengo. En el siglo XVIII, las cargas y prestaciones de tipo feudal que conllevan este tipo de concesiones, fueron objeto de fuerte oposición entre el campesinado (apoyados en algunos casos por la nobleza de la que dependían) y también contrarias al pensamiento ilustrado finisecular. En el siguiente, la reivindicación en favor de la desaparición del régimen foral y la redención de los foros existentes, son una constante del liberalismo progresista.

Arrendamientos originariamente temporales, la perpetuidad de los foros comienza a tomar carta de naturaleza, al mismo tiempo que se suspenden las demandas de despojo, a partir de la Real Provisión de 11 de mayo de 1763. Las políticas regalistas durante el reinado de Carlos III y la acción reivindicativa próxima a la Corte, promovida en favor de sus campesinos aforados, por parte de elementos de la nobleza gallega, como el Marqués de Mos o el de Villafranca al pedir permiso al Rey en 1762 para hacer perpetuos sus foros del Bierzo (a quién en su día citara como ejemplo el Marqués de Camarasa); se tradujeron a partir de la Pragmática de 1763 (y concordantes como la Real Cédula de 1768) en ordenar a la Real Audiencia de Galicia la paralización -interina e indefinida- de los procesos de desahucio y reversiones al dominio directo, respecto a aquellas cartas forales, cuyos elementos clásicos se definieron entre los siglos XVI y XVII ("época clásica”) ${ }^{2}$. Podían darse casos de aforamiento sin cargas o con pagos por importe ínfimo. En estos casos pudiera tratarse de formas de ocultar una transmisión (fijar un heredero, efectuar

1 Gaceta de Madrid, número 202, 21 de julio de 1886: Preámbulo del Proyecto de Ley de redención de censos, elaborado el 3 de julio de 1886 por el Ministro de Fomento, Eugenio Montero Ríos

2 Villares Paz, R. (1985): 10; "Caseiros, rendeiros e foreiros: sobre as formas de cesión da terra en Galicia”; Encrucillada, no 41 
una donación) o bien buscar simplemente el reconocimiento de un señorío por parte del tomador o tomadores del foro.

El abogado Basilio Besada en 1849 -y en la misma línea el tratadista ourensano Gumersindo Buján en 1902- entendían claramente definidos y diferenciados los términos "foro" y "enfiteusis" pia cuando aparece o se hace evidente el foro, como un uso feudal tradicional. Es decir, por una parte se habría incorporado al derecho positivo el antiguo contrato enfitéutico de derecho romano $y$, en un momento posterior no bien definido, es posible confirmar la existencia de un tipo de contrato con matices enfitéuticos, pero consuetudinario y feudal, que es el foro ordinario. Y además, ni uno ni el otro pueden equipararse al censo, toda vez que no existe entrega de capital a cambio del percibo de una renta (temporal o perpetua) o pensión vitalicia. En estas relaciones consuetudinarias constituidas entre desiguales jurídicos (como corresponde al vínculo feudal), de duración temporal ${ }^{4}$, no puede entenderse que el señor renuncie a su dominio

Son determinantes - siguiendo a Buján - las notas distintivas entre ambas formas de cesión de tierras: " $1 .^{\mathrm{a}}$, el foro es de naturaleza temporal; $2 .^{\mathrm{a}}$, en los foros no es admisible la pena de comiso (sin embargo, alguna escritura examinada, como la del foro "La Granja de La Cueva"5 contradice este principio, porque sí lo establece); 3. ${ }^{\mathrm{a}}$, el derecho de tanteo no es inherente al foro; $4{ }^{\mathrm{a}}$, tampoco lo es el derecho de

3 González -Besada Vidal, B. (1849): Práctica legal sobre foros y compañias de Galicia. Vigo, Imprenta de D. Ángel Lema (USC-Biblioteca Xeral, signatura DEP ED27 24). Citado también en Buján Buján, Gumersindo (1902): 192, De la propiedad y los foros: estudio jurídico-social, Ourense, Imprenta de A. Otero (Museo do Pobo Galego, signatura 51)

4 La fórmula usual eran tres generaciones y veintinueve años más. Aunque el nuevo forero -la nueva voz-debiera presentarse para renovar su derecho - habitual en los foros monacales del siglo XVI- el sistema se prestaba al fraude al resultar relativamente fácil ocultar las nuevas voces que se iban sucediendo (lo cual era previsible dado que cada renovación era susceptible de aumentar en cargas). Las vidas de foreros como cómputo, pasaron a ser sustituidas por las vidas de los señores $y$, finalmente a partir de la segunda mitad del XVII, por las vidas sucesivas de tres reyes o reinas. A ellas se hizo común añadir dicho periodo a continuación del último rey o última reina.

5 ARCHIVO HISTORICO PROVINCIAL de Ourense (AHP-Ou). Fondos privados/Familias/ Castro-Murias, caja 9766: Carta foral "Granja de la Cueva” en San Mamede de Puga; Santiago de Compostela, 16 de julio de 1706. Esta carta, en papel timbrado de 40 reales - para el año 1706-presenta características clásicas, excepto los veintinueve años tras la última voz: La reversión al directo tras la última voz; la obligación de mantener las casas y bienes en buenas condiciones y ser devueltas con todas las mejoras; deber de presentación ante el otorgante del foro, del hijo o hija nombrado sucesor en el plazo de treinta días; que los bienes aforados no pueden ser divididos entre los sucesores ni pueden ser objeto de venta, cesión o permuta a entidad eclesiástica, colegio, universidad, monasterio u hospital ni asimismo, ser alguna de ellas sucesor ni crear tributos; puede ser vendido el foral a particular ("persona que sea lega, llana y avisada”), con permiso del directo, fijándose como laudemio un quinto del precio de venta; asimismo se establece el comiso de los bienes en caso de incumplimiento. 
laudemio ${ }^{6}$, y $5 .^{\mathrm{a}}$ y última, el foro no es redimible y sí la enfiteusis" ${ }^{\text {" }}$. Y tanto este estudioso, como Gil Villanueva (autor de un estudio-propuesta legislativa para redención de foros, cargas y censos por el estilo), coinciden en señalar que antes de la Real Provisión de 11 de mayo de 1763, los foros eran: "Foro, que equivale á cierta especie de Emphyteusi, ó de Feudo”8. La definición -o indefinición- de la naturaleza jurídica de estos pactos (llámeseles contratos, cesiones o locaciones), fue uno más -y no el menos importante- de los elementos de controversia que enfrentaron a los propietarios de rentas con los intentos legislativos que buscaban la "redención" agraria, facilitando económicamente el acceso a la propiedad perfecta de la explotación familiar tradicional.

Fuera como fuese, el acceso a la propiedad nunca se planteó desprovisto de una importante inversión económica por parte de los campesinos, aferrados de forma recurrente a la tierra que trabajaban. Para salvar ese gran -y prácticamente único- obstáculo, tanto los programas políticos agraristas, como los desarrollos normativos de finales del XIX, intentaron esa particular reforma agraria vinculando los procedimientos de redención con fórmulas de crédito agrícola. De hecho, en los primeros intentos a partir de la Instrucción de junio de 1837 y la Real Orden de abril de 1838, el gran problema para los campesinos fue la formación del capital necesario para redimir, como consecuencia de los elevados tipos de interés: "La formación del capital sentenció determinantemente la aspiración campesina de perfeccionar su semipropiedad"9

\subsection{La nueva clase rentista surgida del beneficio de la tierra y las desamortizaciones}

\subsubsection{Elementos de complejidad: Subforos y divisiones}

La tierra se convirtió en una importante fuente de renta, de la que también se habría de beneficiar una clase social acomodada de hidalgos y burguesía urbana, ajena al trabajo agrícola, vinculada a actividades comerciales, profesionales o industriales. Que no todos los adquirentes, compradores de la renta que pagaban, eran trabajadores directos del terrazgo, es un hecho puesto de manifiesto por diferentes autores, como Ramón Villares o Vallejo Pousada. Para Gumersindo Buján, en el estudio de 1902 citado, el subforo es la clave del embrollo de parcelas, cargas y

6 El laudemio es el derecho que se paga al señor del dominio, cuando se enajenan las tierras y posesiones entregadas en enfiteusis. Según Juan Manuel Paz Novoa nace con la enfiteusis romana y se establece en la legislación de Las Partidas (Ley 29, título 8º Partida V)

7 Buján Buján, G. (1902): 194, De la propiedad... Op. Cit.

8 Gaceta: 11 de mayo de 1763. Citada en Buján Buján, G.: 195, De la propiedad...

9 Vallejo Pousada, R. (1992): 482, "Redención y pervivencia del foro durante la desamortización de Mendizábal”, Anuario de historia del derecho español, nº 62 
subcargas, porque: Primero, se hacía "sin consentimiento ni noticia del primer dominio directo" 10 . Segundo, el medianero - sin real y efectivo dominio útil- era una figura nueva, absorbiendo características de ambas naturalezas, "pues el subforante continuaba siendo dominio útil con relación al concedente, y directo respecto al subforero" 11 . Tercero, para los propietarios primeros, es a este subforante a quién no pueden ser reconocidos los derechos de retracto y laudemio ${ }^{12}$ (también el de comiso) al no ser auténtico propietario.

La división de las fincas no se derivó, como previsión o consecuencia, de las cartas forales. Fue sencillamente un hecho que, en todo caso, derivaba de la necesidad y el crecimiento demográfico. Para la unidad amplia de la familia campesina, residente en el mismo lugar, no representaba en la práctica un problema el fraccionar, repartir e incluso modificar los predios, ya que todos conocían sus lotes y/o hijuelas, además de participar de forma comunal en muchas labores, “... el forero divide, subdivide y modifica a su antojo la superficie de una cosa que no es suya, o la cosa misma; altera los linderos, amén de complicaciones inevitables de todo género, inseparables de este estado agrario é inquilinario que disminuirán cada día más el valor territorial de la propiedad, en el país del foro" 13

A una nueva clase de rentistas era a quienes especialmente interesaba la renovación del contrato foral, ya que con el despojo - al finalizar el plazo de las tres vidas (voces) de reyes- perdían aquellas tierras que habían poseído y disfrutado en foro, convertidos en señores y que a su vez, habían traspasado con rentas más crecidas a otros subforeros. Ni verdaderos señores ni agricultores útiles, eran sin embargo los grandes interesados en la renovación, pues con el despojo pierden sus rentas. Surgieron intereses comunes; rentistas medianeros y campesinos trabajadores resultaron aliados para impedir la reversión de las tierras al dominio original. Por descontado - como señala Buján - la renta tiende a crecer con cada transacción. Esto cubre la tierra con tales cargas, que aun siendo productiva, acaba por perder su rentabilidad.

\subsubsection{Diversas cargas sobre los bienes aforados}

El derecho de comiso de las tierras podía ejercitarse no solamente en caso de morosidad en el pago de rentas o incumplimiento de servicios, sino también por la división - no permitida - de los bienes aforados. Pese a comisos y coerciones, la reali-

10 Buján Buján, G. (1902): 182, De la propiedad y los foros... Op. Cit.

11 Ibidem

12 Ibidem

13 UNIVERSIDAD DE SANTIAGO DE COMPOSTELA (USC) Biblioteca Concepción Arenal, signatura DEP A63277; CAMARASA, Marqués de (1909): Los foros. CATECISMO del propietario y forero de propiedad aforada, del dueño y pagador de renta foral desamortizada, del comprador $y$ forero de propiedad aforada civil; Establecimiento tipográfico de Fortanet, Madrid, p. 37 
dad es que la indivisibilidad quedó "reducida á la categoría de mera fórmula, pues ni se cumplió ni se respetó, dividiéndose y subdividiéndose al través de la sucesión de varias generaciones los bienes aforados, lo mismo que los que no lo eran"14. No obstante el hecho, la legalidad y sus mecanismos de aplicación garantizaron los derechos del dominio directo, en razón del título hipotecario que nace sobre los bienes y el principio de solidaridad que regía los contratos. Por este principio de solidaridad, el cargo de cabezalero, corresponde a aquel que "tiene el deber de entregar la pensión íntegra al dominio directo, cobrando de los demás pagadores las porciones que les correspondan y agregando él la suya" ${ }^{15}$. Ahora bien, mientras el señor puede exigir del cabezalero el pago íntegro, éste último no puede exigir nada más que a cada consorte su parte correspondiente. He aquí una importante razón - de hecho, la razón- para huir de la condición de cabezalero o, en su defecto, ocultarla en lo posible, sumando confusión a la ya existente con las divisiones e hijuelas en los bienes aforados. Pero no todo el mundo entendía que debiera regir el principio de solidaridad en el cargo de cabezalero. El abogado Juan Manuel Paz Novoa, ponente que habría de ser en Cortes de la Ley de 1873, señalaba en 1872 como anomalía respecto a esa condición que "Sin constar estipulada la solidaridad, se sobreentienda o se presuma" ${ }^{16}$.

Se fundamenta dicha solidaridad en el supuesto de que el dueño del directo tiene una hipoteca tácita en los bienes aforados y de que por la tanto es indivisa la acción y solidaria la obligación foral. De tal forma preponderaba casi constantemente en los fallos de los juzgados y tribunales de Galicia, habiéndose dado el caso de que el Tribunal Supremo (TS) la aceptase y estableciese como regla de jurisprudencia (Sentencia del TS de 9 de mayo de 1861). Dice Paz Novoa, apoyándose en la doctrina ajustada a la letra y espíritu de la Ley 10, título $1^{\circ}$, libro 10 de la Novísima Recopilación de leyes españolas, sostenida entre otros juristas por los señores Laserna y Montalbán (Elementos de Derecho civil y penal de España, tomo $2^{\circ}$, p. 201, edición de 1869), que:

“... las obligaciones en que hay varios deudores acerca de una misma cosa o cantidad, se reputan simplemente mancomunadas, a no ser que conste lo contrario, espresandose en el contrato que cada uno se obliga in solidum, en cuyo caso reciben el nombre de obligaciones solidarias. De esta capital diferencia resulta que en las primeras, cada uno de los obligados sólo puede ser

14 Buján Buján, G. (1902): 185 De la propiedad... Op. Cit.

15 Idem P. 189

16 Paz Novoa, J. M. (1872): 26, Los Foros de Galicia; Imprenta de D. Francisco Paz; Ourense; BIBLIOTECA UNIVERSIDAD DE VIGO (BUV Bca) Campus de Ourense. Signatura OUR 61005. Se recogen los artículos que sobre foros Paz Novoa había publicado anteriormente en El Correo de Galicia. 
reconvenido por su parte proporcional, al paso que en las segundas puede el acreedor exigir de cualquiera de los obligados el pago total de la deuda" ${ }^{17}$

\subsubsection{La onerosa importancia de apeos, prorrateos y laudemios}

Relacionada con el principio de solidaridad del que hablamos, está la necesidad de conocer con detalle las fincas y deslindar las cargas que corresponden a cada uno, "cuyos lindes, términos y demarcaciones se obscurecen ó borran en el transcurso de sucesiones y contratos"18. Para ello servían los procedimientos de apeo y prorrateo, con objeto de determinar los bienes y los obligados a pagar rentas. El procedimiento, oneroso y complicado, es en principio obligación de los pagadores de renta, "... rico filón de curiales y carga dispendiosa para foreros"19. Considerado por juristas como Gil Villanueva como "ruina de foratarios"20, se entiende la razón por la que los labradores no participaran del gusto por la transparencia en cuanto a la identificación de bienes fraccionados, vencimientos y sujetos obligados por solidaridad. Sin embargo y a pesar de valorar como ruinoso el apeo, cuyos gastos estima que pueden llegar a más del triple del capital al añadir el prorrateo; dicho jurista está convencido que conforme a derecho ${ }^{21}$ y siempre y cuando la confusión de lindes no exista, es razonable que el juicio de deslinde no sea a cuenta del censualista. Caso distinto es el prorrateo, respecto al cual está convencido de la improcedencia de "un nuevo prorrateo general cuando el primero existe" y el dueño directo "tiene en su favor la solidaridad" 22 al poder exigir a cualquiera de los pagadores de renta, el importe de la misma. Con buen tino Villanueva hace observación de la posibilidad - respecto al cabezalero de la renta- que "Distribuida entre varios pagadores la totalidad de la pensión, no habiendo quien se encargue de señalar un día para reunir las cuotas, se corre el riesgo de que el dueño directo, usando del derecho de solidaridad, dirija su acción contra cualquiera de ellos." ${ }^{23}$

El prorrateo, desde la perspectiva del dominio directo, es un recurso al que debe acudir como víctima de los abusos e incumplimientos respecto a la carta foral.

17 Paz Novoa, J. M. (1872): 28, Los Foros de Galicia... Op. Cit.

18 Buján Buján, G.: 190, De la propiedad... Op. Cit.

19 Idem P. 191

20 Gil Villanueva, J. (1899): 22, Proyecto de Informe acerca del Derecho Foral de Galicia; Imprenta de José María Paredes; Santiago; Minerva-Repositorio institucional de la Universidad de Santiago de Compostela (USC)

21 Gaceta de Madrid, núm. 206, de 25 de julio de 1889. Ministerio de Gracia y Justicia, Real Decreto de 24 de julio de 1889, por el que se publica el Código Civil. Dice el artículo 1.647: "Cada veintinueve años podrá el dueño directo exigir el reconocimiento de su derecho por el que se encuentre en posesión de la finca enfitéutica-Los gastos del reconocimiento serán de cuenta del enfiteuta..."

22 Gil Villanueva, J.: 23 a 25, Proyecto de Informe acerca del Derecho Foral... Op. Cit.

23 Idem P. 25 
"La modificación desfigura y borra". Por eso los propietarios, a pesar de continuos apeos y prorrateos, no saben cuál es la finca aforada, "teniendo nuevos colindantes y nuevos dueños" 24 . Largos procesos y pleitos; sobre aquél foral de 1706 citado anteriormente, llamado "Granja de la Cueva", se comienza en 1841 un memorial de los bienes con sus límites y demarcaciones, para continuar identificando a los llevadores y poseedores. Continúa una declaración de pleito en mayo de 1851, solicitando reconocimiento y apeo. Prosigue en 1853 por atrasos de los años 1837 y 1839 y en abril de 1857 finalmente dos pagadores de renta reconocen deudas desde $1848^{25}$.

Respecto al alcance de hecho del derecho de laudemio, puede apreciarse aplicado a un caso real, como el que el propio Paz Novoa gestionó en persona. Interviniendo como abogado en un pleito en el cual el dueño del directo dominio exigía de un nuevo forero, comprador de una casa, la quinta parte del precio por laudemio según constaba estipulado en el título de la imposición. La finca la había comprado el nuevo forero en 140.000 reales y se reclamaban 28.000 de laudemio. Sin embargo, la pensión anual era nada más que de 180 reales, que aun capitalizados al 3 por 100, dan un resultado de 6.000 reales, que sería a lo sumo el valor del predio cuando fue dado en foro ${ }^{26}$.

\subsection{La desaparición de los señoríos jurisdiccionales. Desamortizaciones. Conflictivi- dad y nuevos beneficiarios de rentas forales}

Las Cortes de Cádiz en agosto de 1811 habían decretado la abolición e incorporación al Estado de los señoríos jurisdiccionales ${ }^{27}$, que de manera definitiva desaparecieron en 1837. Aquellos censos y concesiones similares, que no formaron parte de la masa de tierras integrada en el dominio público, pasaron a ser considerados a partir de ahí, como contratos entre particulares ${ }^{28}$. Abolir señoríos, contemplados como reminiscencia estamental o jurisdiccional del antiguo régimen, no quiere decir que necesariamente haya de producir consecuencias directas sobre la propiedad territorial. Y de hecho no fue así. Desde las leyes de Cádiz hasta las desamortizadoras, a pesar de la apariencia, la realidad posterior demostró que su repercusión

24 USC-Biblioteca Concepción Arenal, signatura DEP A63277; CAMARASA, Marqués de (1909): 37, Los foros. CATECISMO del propietario... Op. Cit.

25 AHP-Ou; Fondos privados, Documentos familias, Familia Castro-Murias; Caja 9766, C. $182 / 5(1)$

26 Paz Novoa, J.M.: 31, Los Foros de Galicia... Op. Cit.

27 "El redactor general (Cádiz, agosto de 1811)"; El redactor general (1811-1813); Imprenta del Estado Mayor General, 1811-1813; Biblioteca Pública del Estado en Cádiz, Signatura: 33

28 "... a excepción de los que procedan de contrato libre en uso del sagrado derecho de la propiedad.” (artículo 4): "El redactor general (Cádiz, agosto de 1811)”; op. Cit. 
en los grandes propietarios fue moderada y garantista. Cuando el Conde de Toreno comenta el Decreto de enero de 1813, sobre enajenación y venta de propios y baldíos, nos deja ver con claridad algo que era de general opinión, respecto al aprovechamiento y racionalidad de la producción agrícola: "Pues sabido es que el progreso y la perfección de ésta no consiste precisamente en dividir y subdividir las propiedades (...) ni tampoco en cultivar mucho, sino en cultivar bien (...) cuyo objeto no se logra por los escasos y débiles medios que acompañan al desvalido bracero, más sí por los que concurren en el hombre industrioso y acaudalado"29.

Si bien se impuso la obligación de presentar los títulos de adquisición para que los señoríos territoriales y solariegos se considerasen en la clase de propiedad particular, en aplicación del Decreto de las Cortes de Cádiz de 6 de agosto de 1811 y la Ley de Señoríos sancionada el 3 de mayo de 1823, repuestas en todo su vigor por el Decreto de Cortes de 2 de febrero de $1837^{30}$; cuando se desarrolla el procedimiento por el cual se ha de justificar documentalmente el carácter de tales posesiones, mediante Decreto de Cortes de 26 de agosto de $1837^{31}$, se establecen en su articulado (especialmente su artículo $3^{\circ}$ ) otras fórmulas que sustituyen o alteran esta obligación. La consecuencia de hecho era que un señorío territorial, apelando a estas excepciones, en caso de litigio conseguía invertir la carga de la prueba y eran aquellos que afirmaban el sometimiento de determinado territorio a un señorío jurisdiccional, quienes debían demostrar la insuficiencia del título alternativo de propiedad particular ${ }^{32}$, si pretendían suspender la obligación de pagar rentas.

En los primeros años del reinado de Fernando VII, se denunciaron por parte de la nobleza propietaria algunos casos de agresiones y violencias sobre propiedades y personas. Tales hechos habrían sido considerados como un nocivo efecto nacional de las reformas impuestas por las Cortes gaditanas, al abolir la potestad

29 "Guerra de la Independencia. La derrota de Napoleón" (1978): Círculo Amigos de la Historia, S.A, Madrid. A partir de la Historia del levantamiento y guerra de la Independencia, escrita y publicada por Queipo de Llano, J.M. Conde de Toreno (1813). Vol. 3, libro Décimo, p. 9

30 Gaceta de Madrid, núm. 792, 4 de febrero de 1837

31 Gaceta de Madrid, núm. 1.010, 6 de septiembre de 1837. Decreto de las Cortes de 26 de agosto de 1837

32 "Art. 3. ${ }^{\circ}$ Tampoco están obligados los poseedores á presentar los títulos de adquisición para no ser perturbados en la posesión de los predios rústicos y urbanos y de los censos consignativos y reservativos que estando sitos en pueblos y territorios que fueron de su señorí jurisdiccional, les han pertenecido hasta ahora como propiedad particular. Si ocurriere duda ó contradicción sobre esto, deberán los poseedores justificar por otra prueba legal y en un juicio breve y sumario la cualidad de propiedad particular independiente del título de señorío, y será prueba bastante en cuanto á los censos consignativos la escritura de imposición; pero en cuanto á los reservativos, además de la escritura de dación á censo, acreditarán que al tiempo de otorgarla pertenecía la finca gravada al que la dio á censo por título particular diverso del de señorio. La resolución que recaiga en estos juicios, decidirá solo sobre la posesión, quedando salvo el de propiedad." 
jurisdiccional de los señoríos territoriales. En Galicia, un caso paradigmático de conflicto entre nobleza y campesinos, estudiado a conciencia por Baz Vicente, fue el pleito entre la Casa de Alba y los vecinos de Iñás, Dexo y Serantes (A Coruña) ${ }^{33}$. El contencioso fue definitivamente fallado en contra de los vecinos por el Tribunal Supremo en 1859. En esos términos abundó la conflictividad; bien fuera por pleito entre partes como por actuaciones individuales al margen de la ley, derivadas generalmente de la negativa o la imposibilidad de aceptar o hacer frente a la carga de renta. Rentas que como se verá, no eran precisamente simbólicas. Con anterioridad incluso al decreto de Cádiz, se produjeron resistencias por el hecho, como por ejemplo el caso de la destrucción de documentos-registros de bienes aforados en el Monasterio de Melón (Provincia de Ourense), donde en 1809 grupos de civiles campesinos junto a tropas francesas destruyen el "Tombo Dourado"34 de dicho Monasterio. En dicho libro "tumbado" o "Tombo" se recogían los registros que identificaban las tierras y bienes aforados, así como la identidad de las personas. La destrucción de estos documentos en principio impediría identificar las tierras y los pagadores, así como dificultar los desahucios. La conflictividad tuvo carácter general de resistencia pasiva y el efecto de engrosar legajos de pleitos y demandas. Impagos, variaciones de lindes, identidad desconocida de obligados al pago. Incluso casos de estafa, falsificando recibos de pago, como el ejemplo de la querella criminal que en 1815 interpone el Alcalde ordinario de San Esteban de Ribas de Sil (Nogueira de Ramuín-Ourense) en nombre del Mayordomo mayor del Colegio de San Esteban de Ribas de Sil, en un caso de cobro de deudas forales impagadas. ${ }^{35}$ A comienzos del siglo XX, el agrarismo muestra episodios violentos en oposición manifiesta al pago de rentas forales. Estalla tras el gran mitin antiforo de 1908 en forma de talas y quemas de bosque de grandes propietarios, en diversas comarcas coruñesas como Betanzos, Ferrol, Carballo e incluso ataques con dinamita a alguna Casa Consistorial. Los sucesos dieron lugar tanto a actuaciones judiciales como a reacciones políticas e interpelaciones parlamentarias.

La relevancia de toda suerte de resistencias, ilícitos e incumplimientos, en cualquier caso no convirtió en pobres a los ricos. Ni la riqueza cambió de manos ni se alteraron las posiciones de partida de unos y otros. Pero pleitos y demandas sí abundaron. Los derechos de la propiedad se vieron amparados por las instituciones y la justicia, si bien con mayor o menor éxito en su materialización, en función

33 Baz Vicente, M. J. (1992): 41 a 54, "La conflictividad abolicionista en los estados de Andrade: El pleito de Iñás, Dexo y Serantes” Anuario Brigantino, 15

34 AHP-Ou: Tombo dourado universal do Mosteiro de Santa María de Melón, composto por Frei Baltasar González; Fondo Monasterio de Santa María de Melón, L-340 (Restaurado en 1954)

35 AHP-Ou; Fondos judiciales, criminal, Nogueira de Ramuín, caja 8876, 7 de diciembre de 1815 
de la renuencia y/o insolvencia de los obligados. Desde fecha temprana (referida al siglo XIX) pueden acreditarse demandas civiles, documentadas en legajos familiares. Así, respecto a una carta foral de 1790 (foro de "Fondo de Vila", de TrasalvaAmoeiro, familia Castro-Murias, de Ourense), se demanda en 1815 a la viuda de un labrador, la parte de cuota in solidum adeudada por la parte de foro que le corresponde (un ferrado ${ }^{36} \mathrm{de}$ simiente, por la que su renta son seis moyos ${ }^{37}$ de vino), con sus costas y recargos correspondientes, practicando, si no colabora, el prorrateo de oficio. Dos años después, en enero de 1817, todavía prosigue el procedimiento para cobrar de la demandada las cuotas adeudadas ${ }^{38}$. Estamos hablando de poco más de 600 metros cuadrados de finca y más de 1.200 litros de vino de cuota.

Recoge la Novísima Recopilación como el Nuevo Reglamento para la redención de censos y otras cargas enfitéuticas de 1804-1805, había declarado irredimibles los foros temporales del "Reino de Galicia, Asturias y León”. Desde los constitucionalistas de Cádiz hasta las desamortizaciones de 1837 y 1855, la consideración de los arrendamientos y censos temporales (caso de los foros) como contratos entre particulares, los convirtieron de hecho en irredimibles (la figura de la "redención" pagando al dominio directo una cantidad, era propia de aquellos otros censos perpetuos enfitéuticos). En consecuencia: los propietarios no podían recuperar su dominio dada la vigencia de la interdicción impuesta a la reversión desde 1763, ni los pagadores de renta forzar su redención al haber quedado excepcionados los foros gallegos (y los asturianos y leoneses) tanto del Nuevo Reglamento como posteriormente, con la abolición de los señoríos jurisdiccionales y las nuevas medidas económicas capitalistas.

Con la desaparición de los señoríos, aquella clase de rentistas intermedios (o intermediarios), también habría sido favorecida - por los efectos de las leyes desamortizadoras- entre 1837 y 1855. Este periodo es el que Ramón Villares ha periodizado como "Primera crisis del foro"39. Estos hidalgos son señalados como los principales beneficiarios del mantenimiento del sistema de censos y la sus-

36 El ferrado es una unidad de superficie agraria muy usada en Galicia, de dimensiones variables según las diferentes comarcas gallegas. Desde las 0,725 áreas en algunas localidades pontevedresas hasta las 9 áreas en Viana do Bolo (Ourense). En el caso concreto de nuestra viuda, teniendo en cuenta la localidad donde se ubica la finca, se pueden estimar de 6 a 6,30 áreas. Datos obtenidos de: Cañada, S. (Edit.) y Otero Pedrayo, R. (Dir.): Gran Enciclopedia Gallega; impresión de Heraclio Fournier, S.A. - Vitoria, 1984; 102-107 (Xesús Rábade Paredes)

37 Un moyo es una medida para el vino, equivalente a 258 litros

38 AHP-Ou; Fondos privados, Documentos familias, familia Castro-Murias; caja 9763, C. $179 / 3$

39 Villares Paz, R. (1984): 229; "Foros”, en Cañada, S. (Edit.) y Otero Pedrayo, R. (Dir.): Gran Enciclopedia Gallega; impresión de Heraclio Fournier, S.A.: 225-246. Del mismo autor, un clásico de la historiografía foral: Villares Paz, R. (1982): La propiedad de la tierra en Galicia, 1500-1936, Madrid, Ed. Siglo veintiuno de España 
pensión de los desahucios, en opinión de los autores de finales del XIX. Y siguiendo a Villares estos hidalgos habrían sido tanto civiles (comerciantes, industriales, empresarios y profesionales) como militares e incluso una parte del clero -especialmente el secular - vinculado a sus territorios parroquiales. Se optó por favorecer la venta en subasta de Bienes Nacionales en lugar de procurar la redención de los foros y censos que convirtiera en pequeños propietarios a los campesinos explotadores directos de la tierra. En su lugar, el desarrollo normativo permitió la pervivencia durante largo tiempo del sistema, en lugar de ponerle fin. Para el profesor Villares y autores como Vallejo Pousada, los auténticos beneficiados por las desamortizaciones y las rentas forales y subforales, fue la burguesía urbana y comercial, como clase emergente del liberalismo. A este amplio grupo, en el que destacarían comerciales e industriales, Cordero Torrón le asigna la décima parte de las rentas redimidas en A Coruña y las dos décimas en Lugo, durante la etapa de Mendizábal ${ }^{40}$. Un efecto contrario o contradictorio, si se atiene uno a la intención teórica de la Ley de 1837 (o al principio liberal de propiedad perfecta). La venta en subasta de los bienes incorporados al dominio público - gestionada de forma autónoma por juntas provinciales- en la práctica imposibilitó a los campesinos, con mucho menor poder adquisitivo, la compra de sus forales. Y los resultados esperados fueron realmente cuestionables. La hacienda pública no se recuperó y la transacción con los poderes tradicionales necesitó más tiempo y concesiones. Todo ello a pesar de las intenciones manifiestas de cara a ampliar en lo posible el número de compradores, pensando en los más menesterosos: "el empeño de no dividir los terrenos disminuiría notablemente el número de compradores, y se frustrarían las intenciones màs patrióticas del Gobierno" 41 . En resumen, el paso desde el modelo tradicional-feudal al moderno-liberal, se operó a éste y otros efectos, con un carácter "transaccional -y parcialmente burgués"42. Por diversas razones de distinta naturaleza, que no es objeto de este trabajo desarrollar, es obvio que no era ni querido ni factible - anacrónico incluso- pretender articular un sistema que garantizara, frente a cualquier otro interés, un trasvase masivo de bienes y tierras rurales a los campesinos que detentaban su

40 Cordero Torrón, X. (2016): 38; "Los foros en la desamortización. Etapas de Mendizábal y Madoz"; Revista Galega de Economí; Universidad de Santiago de Compostela; Vol. 25-1

41 Gaceta de Madrid, núm. 650, 22 de septiembre de 1836. Real Orden sobre el destino de Conventos y Monasterios.

42 Vallejo Pousada, R. (1983): 496, "Redención y pervivencia del foro durante la desamortización de Mendizábal”, Anuario de historia del derecho español, no 62, 1992. Citado por dicho autor, conforme a la definición de Francisco Tomás y Valiente: Manual de Historia del Derecho español, Madrid, Tecnos, p. 417 
dominio útil. La transición de la que hablamos "se realizó con una solución sólo parcial de la propietarización del campesinado"43.

Así las cosas, habrían sido los grandes arrendatarios los verdaderos beneficiarios de las desamortizaciones propiciadas desde la Ley de 31 mayo de $1837^{44}$. Arrendatarios que responden a un grupo social en auge, cual es la burguesía urbana y más concretamente los compradores de bienes nacionales. En algunos casos, particulares como el del ejemplo tomado para el caso: el expediente de subasta de foros, en el que el mejor ofertante, Manuel Fernández, adquiere mediante puja celebrada en Ourense el 24 de septiembre de 1840, dos foros del Priorato de Coiras (dependiente del Monasterio de Oseira) y uno del Priorato de Lobáns (dependiente del Monasterio de San Paio de Antealtares, en Santiago ${ }^{45}$. El comprador adquiere solamente el dominio eminente, es decir, el derecho a cobrar las rentas de los foreros o poseedores del dominio útil.

Siguiendo a Vallejo, los "bienes nacionales" tenían ocho años de plazo para ser pagados, mientras que para el pago de rentas redimidas el plazo era de cuatro años. Más todavía, se da el caso de disponer de diecisiete años, para pagar 25.100 reales, en una subasta de bienes nacionales de 1862 en A Coruña. ${ }^{46}$ La Ley de mayo de 1837 fue una norma ambigua: reconoce un derecho pero con una regulación que lo impide (obstáculos como capitales elevados y la concurrencia con hipotéticos compradores). En la práctica, ese grupo de nuevos compradores/inversores se habrían subrogado en la posición de los titulares directos primeros de los bienes (aquellos señoríos laicos o, en su mayoría, eclesiásticos). Los foros gallegos -y asturianos- diferenciados del contrato enfitéutico perpetuo por su carácter temporal, quedaron al margen de la redención, pasando sus rentas a ser "compradas" por los nuevos titulares. La desaparición de los señoríos tuvo por efecto, la sustitución de una oligarquía terrateniente por otra: la eclesiástica por la burguesa. Y de esta última, más concretamente, por la de aquel grupo de inversores interesados en hacerse con grandes cantidades de bienes y tierras rurales agrícolas.

43 Cabo Villaverde, M. y Míguez Macho, A. (2015): "El caciquismo adaptativo: poder político, movilización social y opinión pública en la Galicia Rural de la Restauración”, en www.researchgate.net. Este trabajo se enmarca dentro de los proyectos: «Transformaciones en la agricultura atlántica y evolución dela sociedad rural en el franquismo (1936-1975): cambio tecnológico, medioambiente y dinámica socio -política» (HUM2006 - 13499. IP. Lourenzo Fernández Prieto, integrado en el Grupo de Referencia Competitiva: «Historia agraria e política do mundo rural. Séculos XIX e XX». IP: Ramón Villares Paz. Código: 2006/XA024 y «La nacionalización española en Galicia, 1808-1874» (HUM2006-10999. IP Justo Beramendi).

44 Gaceta de Madrid, núm. 913, 3 de junio de 1837

45 AHP-Ou: Fondo Delegación Provincial del Ministerio de Hacienda, C. 2125

46 AHP-Ou: Fondos privados, documentos familias, familia Castro-Murias, caja 9764 C. 180/9. Subasta de bienes nacionales (Fraga da Gesteira-Alvedro-Santiago de Compostela), A Coruña, 12 de agosto de 1862 


\section{Ideas e intenciones políticas. La redención de foros en el marco del reformismo liberal democrático}

\subsection{No reversión, consolidación y propiedad privada. Nuevas ideas para antiguos pro- blemas}

Alguien dijo en alguna ocasión que ningún viejo principio se retira de la escena del mundo sin protestar ni combatir. Mediada la centuria, con los efectos de las desamortizaciones y en venta los bienes nacionales, comienza el periodo nuclear del debate reformista por la cuestión de los foros. En el fondo, otro apartado más de reformas pendientes en España durante la segunda mitad del siglo XIX. Coincide con la generación de 1868, durante la cual la cultura y el pensamiento contribuyen al paso desde el Estado liberal al democrático. En el asunto que nos ocupa, no podemos olvidar al Derecho, toda vez que el transcurrir de los tiempos consolida más a éste que a las instituciones. Abogados y juristas intervienen en el debate foral y son agentes de reforma. También la propiedad se ve de otro modo. Ya no es algo inmutable, sino que como expresaba Nicolás Salmerón, su verdadera legitimidad la obtiene cuando sirve a fines racionales de la vida humana. Relacionado con el derecho a consolidar su propiedad, por parte del campesino gallego, forzando mediante Ley la redención de foros y censos; decía Paz Novoa en 1872 que habría de hacerse libre la propiedad y entonces el hombre sería libre.

En abril de 1842 se había publicado la Memoria de Manuel Colmeiro, en el certamen abierto por la Sociedad económica de Santiago para premiar la mejor Memoria sobre el modo más acertado de remediar los males inherentes a la extremada subdivisión de la propiedad territorial de Galicia. ${ }^{47}$ Colmeiro consideraba beneficiosos los foros ("enajenación paliada”), por contrarrestar en gran parte las funestas consecuencias de la amortización. Pero al mismo tiempo, también los consideraba germen de ciertos males de la agricultura, con defectos capitales como su perniciosa influencia en la industria agrícola gravando la propiedad, entorpeciendo su circulación y castigando las mejoras. Al ser irredimibles sus cargas, son un obstáculo para consolidar el dominio, base de las reformas necesarias para mejorar la agricultura. Para Paz Novoa a partir de este momento aparece - con carácter científico, la doctrina de la redención forzosa de las cargas forales. Veinte años más tarde, en 1864, aparecen los artículos de Castro Bolaño. De alguno de ellos (sobre las cargas perpetuas que afectaban a la propiedad territorial en Galicia), especialmente en lo

47 Folleto de 68 páginas en $4^{\circ}$. Impreso en Santiago por la Viuda e hijos de Compañel. Santiago de Compostela, 1843 
referente al derecho de despojo o desahucio, defendido intensamente por los propietarios, decía Besada respecto a la injusticia de la reversión que:

“...lanzar á los poseedores de sus establecimientos, para instalar en ellos á los dueños del directo, sería defraudar esperanzas legítimas sin ventaja equivalente al mal; porque como dice un jurisconsulto célebre, el placer de la ganancia no compensa nunca el pesar de la pérdida. No; aquí es aplicable un principio profundo de la legislación romana: en igualdad de casos es mejor la condición del que posee por la sola razón de poseer"

Un hito en la cuestión foral fue el Congreso agrícola gallego, celebrado en Santiago en $1864^{48}$. Concurrieron gran número de propietarios, comisiones de corporaciones científicas, oficiales y de enseñanza, así como personajes ilustrados del país. También estuvo presente Eugenio Montero Ríos. No trascendió en nada concreto debido a la oposición de los anti-reformistas. Pedir el mantenimiento del statu quo y el "cumplimiento de los contratos", como así rezaban algunos propietarios (digamos la parte menos radical, renuente a los despojos sin más), previo pago de un capital indemnizatorio, puede parecer a simple vista y en palabras de Paz Novoa, "el summun ius, pero analizando el hecho, es la summa injuria, la iniquidad por excelencia" 49 Otra razón a las anteriores añade Paz Novoa y es que la indemnización al colono por el despojo (reversión con indemnización), no llenaría el fin social que debe tener por objeto la reforma. Lejos de convertir a los campesinos colonos en dueños y elevar su condición social, los convertiría en verdaderos proletarios. Un par de años más tarde, Justo Pelayo Cuesta presenta ante el Congreso de los Diputados una proposición de Ley para la consolidación de dominios sin reversión de predios al dominio directo ${ }^{50}$

La iniciativa legislativa de Pi y Margall en agosto de 1873 -norma de "tiempos revueltos de la Revolución”- como la llamaría más adelante el Marqués de Camarasa; era coherente con su idea respecto a un Estado compuesto por pequeños propietarios -agrícolas en este caso- comprometidos por sus intereses e interés en la "cosa pública". El proyecto respondía al plan de reforma agraria elaborado en mayo de ese mismo año, por una comisión que contaba con expertos como Fermín

48 Congreso agrícola gallego. Actas, discursos, etc. Publicados por orden de la Sociedad económica de Santiago por D. José Planellas Giralt, Secretario que fue de dicho Congreso y de la Comisión preparatoria - 1 volumen, folio menor, de 244 páginas; Imprenta de José Rodríguez Rubial, Santiago de Compostela, 1864

49 Paz Novoa, J.M. (1872): 44, Los Foros de Galicia...Op. Cit.

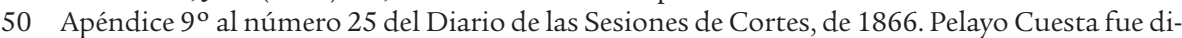
putado y subsecretario. Tras la Primera República fue también miembro de la primera junta directiva de la Institución Libre de Enseñanza, fundada por Giner de los Ríos. Pronunció en 1878 el discurso inaugural. 
Caballero y autoridades como José María Orense. Conforme a aquella idea, el compromiso político y la base social necesarias, en la visión federalista de Pi y Margall tal y como el 27 de mayo y $1^{\circ}$ de junio de 1873 puede leerse en La Igualdad ${ }^{51}$, alejado de tendencias colectivistas y revolucionarias; descansaba sobre la idea de la pequeña propiedad. O si se quiere, "un modo de entender la revolución liberal en favor de las clases populares" 52 . Puede entenderse a partir de su concepción territorial, política y social del Estado, la férrea oposición y el desencuentro con los republicanos centralistas, al constituir esta versión radical y democrática de la revolución liberal, junto a su visión de España, una línea de fractura con el republicanismo burgués y acomodado de los posibilistas de Castelar.

Si el fin último de facilitar la redención de sus rentas era hacer justicia, en definitiva y en palabras de Paz Novoa, a la "historia íntima de la decadencia de Galicia", su argumento político y defensa legislativa para la consolidación de los dominios, sigue la línea social del federalismo de Pi y Margall:

“... también requiere una organización especial de la propiedad privada, única que consideramos acomodada á la naturaleza del hombre, pero distando tanto de las exageraciones del individualismo como de las perturbadoras y quiméricas ficciones del comunismo.

Puede decirse que la historia de la emancipación de la propiedad es la historia de la emancipación del individuo (...) dueño único y exclusivo de sus tierras y su hogar

(...)

Queremos lo que se llama la consolidación de los dominios, que nuestra legislación civil viene ya favoreciendo, si bien indirectamente y con escasos resultados (...) pero la queremos, no sólo para conseguir su fin económico, de alta y trascendental importancia, sinó también para obtener otro fin, eminentemente social, la emancipación de esta especie de proletariado de los campos. Así, elevados los foreros a la condición de dueños absolutos de las tierras que cultiva, alcanzarán con plenitud de su propiedad, la plenitud de su autonomía"s3

En este sentido, definiendo el Estado como lo hace Hobsbawm: "una forma de unir a los súbditos contra la subversión y la disidencia"54; la pérdida de poder central (estatal) que presupone el federalismo republicano, bien podía considerarse

51 La Igualdad: 27 de mayo y 1 de junio de 1873

52 Esteban Navarro, M. A. (1994): “De la esperanza a la frustración, 1868-1873”, en: Townson, N. (Ed.): El republicanismo en España (1830-1977); Alianza Universidad, Madrid, P. 111

53 Paz Novoa, J. M. (1872): 38 y 39, Los Foros de Galicia... Op. cit.

54 Hobsbawm, E. (1998): 159; La era del Imperio, 1875-1914; Crítica, Barcelona 
como subversiva desde el republicanismo centralista. Pese a todo, favorecer la creación de una amplia clase propietaria campesina, con pleno dominio de la tierra que trabaja, constituye una manera de crear ciudadanos con intereses en el sistema, lo cual semeja garantía de estabilidad más que posibilidad de revolución. Con la caída de la República y tras la restauración monárquica, Montero Ríos, partidario de la redención en transición suave, favorecida por la sucesión en el dominio; promovió una nueva iniciativa mediante Real Decreto Legislativo (RDL), el de 1886, que derogó finalmente la Ley de 1873 y remitió la terminación de los expedientes -no ultimados- paralizados por el Decreto de 20 de febrero de 1874, a condición de que las partes se avinieran a finalizar los mismos al amparo de las normas previstas en la disposición de 1886. Dejó sin embargo su aplicación pendiente de posterior desarrollo normativo.

\subsection{La posición de los propietarios}

Contra los Monasterios (de las órdenes de San Bernardo y San Benito) y frente al Marqués de Altamira, Conde de Astorga, se había pronunciado en 1767 el diputado D. Francisco de Zuñiga y Losada en su exposición "La razón natural”, solicitando la abolición de los despojos y la renovación de foros y enfiteusis. Ya se ha citado la férrea oposición (golpe ab iratio decía Paz Novoa) de aquel sector dispuesto a sostener a toda costa el statu quo, con sus rentas, sus prestaciones y sus despojos. Ahora bien, no se trataba únicamente de una cuestión económica; el mantenimiento del sistema tal cual venía siendo secularmente, era también una cuestión política y social. Decía un adversario de las reformas, del cual Paz Novoa recoge sus palabras:

“...mantengamos, pues, lo existente, teniendo en cuenta, que el colono gallego, como propietario, aunque en pequeña escala, es una garantía de orden para la sociedad, porque está interesado en su conservación, al revés de lo que sucede con las grandes masas de obreros industriales, que despojados de toda propiedad, son en otros países un elemento de constante perturbación y una eterna amenaza al capital"55

Pero no era la anterior la postura preeminente entre los propietarios. Entre éstos al igual que otros colectivos, la idea de poner fin a los foros y consolidar los dominios era la más generalizada. Otra cuestión era cómo hacerlo. En otro plano, regionalista, agrarista y propietario también, se daba gran sensibilidad con el problema. El componente social de Solidaridad Gallega, cuyo manifiesto fundacional es de 1907 (A Coruña) obra de Rodrigo Sanz y que contaba con personajes de la

55 Paz Novoa, J. M. (1872): 42, Los Foros de Galicia... Op. cit. 
talla de Moreno Barcia, Manuel Lugrís y colaboradores solidarios como un joven Casares Quiroga (no firmante, sin embargo, del manifiesto); está compuesto en su práctica totalidad por media y alta burguesía (rural y urbana) propietaria (y algunos grandes propietarios como la familia Golpe). Manifiestamente favorables a la redención y partícipes del gran mitin antiforo de 1908 en A Coruña; su idea respecto a la política y reforma agraria se centraba en innovaciones técnicas y exenciones fiscales.

Tanto a través de artículos y folletos como mediante la oposición parlamentaria, muchas de las ideas de propietarios (grandes y menos grandes) y rentistas, fueron recogidas y profusamente divulgadas por sus representantes sociales y políticos, entre los que podemos citar a Mon y Landa y, de manera concreta para este trabajo, al Marqués de Camarasa: Ignacio Fernández de Henestrosa y Ortiz de Mioño, VIII Conde de Moriana del Río, VIII Marqués de Cilleruelo y por vía de su matrimonio, XV Marqués de Camarasa (linaje con "grandeza de España” desde 1626) y XIV Conde de Ricla. Como "obra habilísima de intereses bastardos ayudados por la ignorancia, la malicia y el embuste" ${ }^{56}$, califica el Marqués la suspensión de derechos forales en 1763. Un "despojo hipócrita" es para él la redención forzo$\mathrm{sa}^{57}$. El problema no sería una cuestión agraria ni regionalista, sino de propiedad y libre contratación, que se presenta por igual en muchas provincias españolas, con fundamento en la legislación castellana y cuyos orígenes medievales no son ciertos y/o no están demostrados. De hecho, para el Marqués, era en el Ministerio de Gracia y Justicia y no el de Fomento donde recaía la responsabilidad de dar solución jurídica a la cuestión de los foros ${ }^{58}$. Y la llamada redención no es sino una compraventa. Al mismo tiempo, era importante a la hora de "redimir", diferenciar los que fueran terrenos incultos o eriales en origen, de aquellas otras zonas ya fértiles y en cultivo. Para el Marqués la acumulación de propiedades deriva del sistema de las vinculaciones y mayorazgos. Casas nobiliarias como Alba, Lemos, Andrade, Altamira, Castelar, Camarasa, Rubianes, Villafranca... aun reuniendo grandes masas de pequeños foros, no constituirían la mayoría. La cuestión que defiende no es solamente en favor de los "grandes", sino que: "Están en juego derechos de infinitas personas en muchos casos de modestísima genealogía y posición... Además esa ley no puede prosperar porque sería anticonstitucional"59

56 USC-Biblioteca Concepción Arenal, signatura DEP A63277; CAMARASA, Marqués de (1909): Los foros. CATECISMO del propietario... Op. Cit. P. 13

57 Idem. P. 27

58 La Época, 9 de septiembre de 1886, núm. 12.261, p. 1

59 USC-Biblioteca Concepción Arenal, signatura DEP A63277; CAMARASA, Marqués de: 30; Los foros. CATECISMO del propietario... Op. Cit. 
El desorden, el mal que padecía la propiedad territorial en la "región del foro", siguiendo a dicho autor, era precisamente la separación de los dominios y el incumplimiento de los contratos (subdividir, modificar lindes, ocultación de los obligados al pago...). El remedio, obviamente pasaba por la consolidación de los dominios y el respeto a los derechos de propiedad y libre contratación "en lo posible” y siempre suficientemente indemnizados. Y esto último es interesante, porque muestra algo que también se hacía manifiesto a comienzos del siglo XX (el Marqués afirmaba esto último en 1909): La disposición de las familias nobiliarias a vender suelo y propiedades en Galicia. Propiedades que reunían en ocasiones diferentes grandes casas y pazos, en los que nunca habitaban y no se hallaban adecuadamente acondicionados o cuidados. Pero vender a buen precio y en condiciones de libre mercado.

En esos términos, al proyecto de Ley de Eduardo Vincenti - quien en 1886 había contestado al Marqués que la redención no es otra cosa sino "adquisición por justo precio de su propiedad"60 - le otorga nuestro autor mejor consideración porque, aun siendo su solución tan arbitraria como las anteriores, al menos su redención "es algo más eficaz que la de aquellos, porque su tipo de capitalización es más alto". Esta disposición a vender "con provecho de todos" 61 , es la que la Casa de Camarasa argumenta con diversos ejemplos como el del Marqués de Alcañices-Duque de Sesto (permitiendo la consolidación de dominios a favor de sus foreros, con capitalización de la renta al 5\% y pago en dos años) o los duques de Plasencia. La Casa de Camarasa era asimismo propietaria de un gran número de foros pagados por la mayoría de los vecinos de tres pueblos en la comarca ourensana de Valdeorras, que en el último cuarto del siglo XIX permutaran estos foros por una finca libre, propia de dichos pueblos. Sobre este terreno discurría la línea férrea del noroeste. Dicho terreno (al que denomina Campo Grande), dividido en parcelas, fue adquirido a solicitud de varios vecinos de estos pueblos, redundando - en palabras del Marqués- en la "consolidación a favor de centenares de foreros"62

De manera sucesiva, la interinidad permanente de la Pragmática de 1763, la consideración de no redimibles de los foros gallegos-asturianos-leoneses y la consideración de contratos entre particulares a la que se habían reducido desde 1811 los foros y censos no incorporados al Estado, así como el traslado de las rentas

60 Vincenti Reguera, E. (1886): 34; La ley de redención de censos del señor Montero Ríos y la propiedad foral en Galicia: contestación al señor Marqués de Camarasa; Madrid, Tipografía de Manuel Ginés Hernández, Biblioteca digital de Castilla-León, Ref. 9020

61 USC-Biblioteca Concepción Arenal, signatura DEP A63277; CAMARASA, Marqués de: Los foros. CATECISMO del propietario... Op. Cit.: Cuestiones diversas en el epílogo del "Catecismo" propietario 
forales al grupo de inversores-compradores de bienes nacionales desamortizados -aun cuando se les hubiera dado carácter de redimibles a dichas rentas- tendían a reconducir el problema a una cuestión contractual y de derecho entre particulares $^{63}$. Encajada la materia en este molde, cualquier otra dimensión social, política o económico-productiva se disuelve o se deforma. Por consiguiente, el problema de fondo podía resumirse en el dilema de si el núcleo esencial de las obligaciones contractuales es perfecta y legalmente variable o bien inquebrantable sin más. Con su peso de jurista se pronunciaba así Jove y Bravo en 1883:

"Hoy es el contrato de <<foro〉> el que se hace pedazos en beneficio de una de las partes; mañana será el contrato de arrendamiento el que se romperá en favor de los arrendatarios. La excepción que se introduce en un principio jurídico fundamental, es la primera piedra que se arranca a la base en que descansa (...) con la redención forzosa se quita esa clave (...) Si el principio de las obligaciones es un axioma jurídico, es absolutamente necesario mantenerlo a todo trance, en todos los actos jurídicos; si no tiene ese carácter, si es contingente, se hace preciso reconocerlo así solemnemente, porque la ley debe ser igual para todos.

Nadie sostendrá seguramente que el principio a que nos referimos es esencialmente variable, luego la redención forzosa es contraria a derecho" ${ }^{\prime 4}$

Pese a esa imagen de impotencia y discriminación respecto a una de las partes del "contrato" que se nos presenta como dilema grave de la cuestión (imposibilidad de recuperar los bienes, venta forzosa con tintes de expropiación, incumplimientos de los arrendatarios que conculcan el contrato...); el apeo y prorrateo era un recurso y procedimiento habitual, del que dejan constancia las abundantes "memorias de bienes" y expedientes de prorrateo a lo largo de todo el siglo XIX (algunos ciertamente largos, como el citado "Granja de la Cueva", comenzado en 1841 y concluido en 1857). El amparo de la jurisdicción civil siempre fue un recurso real y en la medida de las posibilidades, eficaz. Otro recurso era señalar al cabezalero como responsable de la identificación de los llevadores de bienes para prorrateo

63 Gazeta de Madrid, núm. 913, 3 de junio de 1837: Decreto de las Cortes de 31 de mayo 1837: Artículo $1^{\circ}$. Se declaran en estado de redención, con arreglo a lo propuesto en Real Decreto de 5 de mayo de 1836 y demás determinaciones y aclaraciones posteriores, todas las cargas o rentas exigidas con el título de foro, enfiteusis o de arrendamiento cuya fecha sea anterior al año 1800 que se pagan por pensiones, caseríos, tierras, cotos o lugares pertenecientes a las Comunidades y Monasterios extinguidos de ambos sexos.

64 Jove y Bravo, J. M. R. (1883), del Colegio de Abogados de Oviedo: Los foros. Estudio histórico y doctrinal, bibliográfico y crítico de los foros, en Galicia y Asturias. Biblioteca jurídica de autores españoles, Imprenta de la revista de legislación, Madrid ("La muerte del foro sería la de todo contrato"). Una reproducción de la obra publicada por Maxtor, Valladolid, 2007 
y exigencia del pago de atrasos (demandados siempre con los correspondientes intereses y costas). Se recurrió a ello en el caso del foral "del Palacio, en la Puebla", correspondiente al dominio del Conde de Ribadavia (marquesado de Camarasa), en 1824; donde el cabezalero señalado identifica hasta doce partidas ${ }^{65}$. Y por otra parte, en casos de morosidad de los arrendatarios era posible que un tercero se hiciera con su partida si podía hacer frente a la renta. Así resultó en el expediente del foral "Pendello" en Sta. María de Melias - Ourense, de 1839, donde la imposibilidad (por indigencia) de pagar los atrasos de dicho foral (que tiene por renta 20 cuartos de vino y dos reales), obligó al deudor a hacer dejación de su partida, ante el auditorio señalado y el ejecutor del expediente, en beneficio de otro que pudo hacerse cargo de dicha renta (aunque no de los atrasos, que continuaron siendo responsabilidad del deudor $)^{66}$

\section{La resolución de la cuestión foral}

\subsection{La propuesta de Ley del Marqués de Camarasa y la "solución equitativa" de Mar- tínez Sueiro}

Siendo el propio Marqués uno de los principales grandes propietarios de Galicia, dirigió en 1885 a los senadores una propuesta de adición a la base 26 del proyecto de Código Civil. Fue la más férrea oposición al proyecto de Ley de Montero Ríos, divulgando ampliamente sus ideas y propuestas a través de publicaciones y periódicos, como su "catecismo" o las columnas de La Época. Señaló con insistencia la necesidad de diferenciar el foro temporal (o arriendo enfitéutico) del foro perpetuo (o censo enfitéutico), así como entre los foros anteriores (redimibles) y los posteriores (no redimibles) a 1800. El proyecto publicado en 1909, que se enfrentaba a la redención forzosa tal como habían entendido las normas de 1873 y 1886, proponía una "Ley para la consolidación de dominios". Propugnaba la derogación de la Real Provisión de 11 de mayo de 1763 (que había paralizado los desahucios) y la conservación en vigor de la Ley de 31 de mayo de 1837, que declaraba redimibles los foros procedentes de la desamortización. En su proyectado artículo $4^{\circ}$, se preveía la admisión de las demandas de consolidación de dominios por parte de los Tribunales, definidas previamente en cuatro modalidades, según se tratase de terrenos

65 AHP-Ou; Fondos judiciales, pleito de foros: Real provisión ordinaria de prorrateos, para hacerlo del foral del Palacio, en La Puebla, del dominio del Conde de Ribadavia; caja 8851, año de 1824

66 AHP-Ou; Fondos privados, Documentos familias, familia Castro-Murias; caja 9763, C. 179/6, 7 de mayo de 1858 
en cultivo o incultos y en función de a quién correspondía la iniciativa ${ }^{67}$. Manuel Martínez Sueiro, al exponer y comentar dichos proyectos en el año 1912 previo a su solución intermedia, ejemplifica elocuentemente el capital indemnizatorio calculado para ambos casos, resultando que una diferencia entre pensión foral y arrendamiento de 50 pesetas, capitalizaría a favor del campesino forero 1.250 pesetas, mientras que a favor del propietario aforante serían 1.668 al contado o 2.000 en dos plazos. Por último, señalar algo que venía siendo recurrente: que estos proyectos quedaban a expensas de operaciones del Catastro y a que pudieran practicarse después un apeo y prorrateo general. Por su aparente dificultad o la falta de interés, Domingo Enrique Aller decía de forma elocuente respecto a dicho catastro, que del mismo "no dispondrán nuestros nietos".

La propuesta de Manuel Martínez Sueiro ${ }^{68}$ se presentó como "voz de concordia y no de lucha", premiada en los juegos florales celebrados en Santiago de Compostela, durante las fiestas del apóstol de 1912. Intelectual y Juez - del que se ha destacado su faceta entre historiador y sociólogo- desde una perspectiva armonicista acorde con su ideario moderado, católico y liberal, recoge en su proyecto aquellos planteamientos o aspiraciones socialmente más reformistas, conjugadas con el derecho e interés del propietario. Intuyendo, quizá, que era aquella cuestión -la desaparición de los foros y la consolidación de los dominios- una asignatura inexplicablemente pendiente y foco de posibles y futuras tensiones sociales: "la redención hízose ley desde hace muchos años; falta solo determinar las condiciones. Es, pues, el legislador español un deudor moroso de los foratarios gallegos" ${ }^{69}$. Las cuestiones relativas a la temporalidad o indefinición de los foros y subforos, así como la aplicación de tipos variables, cargas (laudemios, apeos, prorrateos), lotes redimibles... seguían líneas similares a las propuestas finiseculares, como la de Montero Ríos. Al mismo tiempo, las soluciones relativas a la reversión y consolidación se aproximaban a los intereses de los propietarios reales, en la línea defendida por el Marqués de Camarasa.

Respecto a los Bancos agrícolas, tanto Martínez Sueiro como Paz Novoa eran escépticos respecto a ellos, "que ni aun al 4 ni al 3 por 100 puede el labrador de

67 USC-Biblioteca Concepción Arenal, signatura DEP A63277; CAMARASA, Marqués de: 4751; Los foros. CATECISMO del propietario... Op. Cit.

68 Martínez Sueiro, M. (1912): 59, La cuestión agraria en Galicia. Redención de foros y subforos. Una solución equitativa; Imp. Pap. y Enc. LA POPULAR; Ourense

Esta monografía comentada también por Rafael Tabarés Pérez-Piñeiro, citada en el estudio biográfico sobre Martínez Sueiro elaborado por Barbosa Lorenzo, C. (1999): 115 a 125, "Manuel Martinez Sueiro. Entre la Historia y la Sociología”; Minius VII

69 Martínez Sueiro, M. (1912): 41, La cuestión agraria en Galicia. Redención de foros y subforos... Op. Cit. 
ordinario amortizar capitales en poco tiempo"70. Paz Novoa en 1872, a pesar de valorar positivamente la creación de una Banca pública, destinada a facilitar créditos "blandos", inspirada en el modelo alemán de $1770^{71}$ opinaba que no era ésta una solución realista, por la dificultad de que se otorgaran créditos a personas que con lo único que realmente podían responder era con una "propiedad" cuyo dominio real no ostentaban ${ }^{72}$.

Sobre la concentración de parcelas fue sumamente escéptico: El aumento demográfico favorece el fraccionamiento (hijuelas que reparten la herencia entre los sucesores). Y por las características geográficas (un terreno sumamente irregular, cruzado de ríos, arroyos y torrentes). Si el tipo de indivisibilidad es grande, se disminuye la capacidad adquisitiva de los campesinos más humildes, que son la gran mayoría y que de hecho ocurrió con los lotes de bienes nacionales sacados a subasta partir de 1837, por razón de su "tamaño" (que decidían las juntas provinciales) y precio. Finalmente, Martínez Sueiro da otra razón de tipo etnográfico-cultural: "Porque nuestros campesinos aman la tierra hasta el crimen y causaría incalculables trastornos cualquier medida que pugnase de frente con el statu quo", sin adaptarse jamás a la realidad de las cosas”. Asimismo, cita como ejemplo ilustrativo el fallido intento en 1873 de Eduardo Chao para concentrar tierras inferiores a dos hectáreas. Dice que fue suficiente que un Secretario de Ayuntamiento (José Barbeito) le demostrase que dejaría sin tierras a la mayoría de los campesinos. Una particular manera de concentrar tierras, por la que apostaba Martínez Sueiro, era que los vecinos pudieran, previo pago, ser preferentes en la adjudicación de las fincas del fallecido en los casos de intestato. En general, estimular el derecho a la anexión de las fincas de menor tamaño por parte de los poseedores de terrenos colindantes, preferiblemente aquellos con fincas más pequeñas

\subsection{El problema agrario desde el regionalismo}

Con posterioridad a los "solidarios" de 1907, el nacionalismo, desde su articulación a través de las Irmandades da Fala en 1916, recoge en esta cuestión los resultados y propuestas de las asambleas agrarias de Monforte entre 1908 y 1911. Tam-

70 Idem P. 64

71 Paz Novoa se refiere al modelo alemán inspirado en la idea del negociante berlinés Herr Buhring, en la Prusia de Federico el Grande. El reintegro del capital se verificaría al 1 por cien de amortización más el 4 o 5 por cien de intereses, en 25 o 30 años

72 “Pero podemos aspirar á verlos establecidos en nuestro país, dada la actual organización de la propiedad inmueble? De ningún modo. Baste observar que son establecimientos de crédito, y que el crédito no podría otorgarse al que, como el labrador gallego, sólo habría de presentar cono garantías de solvabilidad fincas sujetas al foro, con toda la série de gravísimos inconvenientes que en este capítulo bemos bosquejado." Paz Novoa, J.M. (1872): 37, Los Foros de Galicia... Op. cit. 
bién sensible hacia el problema foral, considera claramente que debe desaparecer. Sin embargo, no se llegó a proyectar de forma concreta un mecanismo normativo de redención. En sus planteamientos, junto con el anti-caciquismo y anti-cunerismo; las propuestas discurren principalmente por el terreno modernizador, librecambista y de racionalización productiva. Se demandaba el impulso del ferrocarril, la privatización de montes públicos y la creación de cooperativas e instituciones de crédito agrícola en condiciones favorables al pequeño campesino propietario, además de otras medidas comerciales y fiscales. En la cuestión de las propiedades aforadas y/o arrendadas, se enfatizaba en el perjuicio que suponían los grandes propietarios absentistas y la dificultad de un aprovechamiento racional y productivo de estas tierras. En el manifiesto nacionalista se incluía otra cuestión relacionada indirectamente, como era la recuperación de la figura jurídica de la compañía familiar gallega. Lo anterior permite deducir que el nacionalismo en sus años de desarrollo cultural y político, desde las Irmandades hasta o rexurdimento en los años 20 , no se planteaba la redención foral como producto legislativo concreto, tal como en el último cuarto del siglo anterior se había intentado, sino como resultado de factores relacionados con la inversión, las infraestructuras, la economía y el autogobierno. En términos generales, el labrador que no era ya propietario completo de sus predios, en la práctica tampoco corría riesgo de perderlos en aras del derecho de reversión al dominio directo.

Parecía que de nuevo, la apuesta por crear aquella ciudadanía de pequeños propietarios, pasaba por la combinación de medidas económicas, políticas, sociales y de regulación jurídica; pero más allá de una única norma "redentora" de los arrendamientos a foro. En su lugar, junto con el acceso a la masa de tierras sin explotar de las grandes propiedades, la solución pasaba por políticas públicas inversoras, la mejora económica de la familia campesina y la explotación agraria, así como la facilidad crediticia para comprar (ya fueran sus rentas, bienes, tierras...) y/o invertir.

\subsection{La extinción de los foros}

Aquella "Ley especial” a la que se refería el Código Civil (en su artículo 1.611), es la que invoca Primo de Rivera para someter a aprobación y firma real el 25 de junio de 1926, el Real Decreto Ley sobre redención de foros, subforos, rentas en saco, sisas, foros frumentarios, derechuras, cédulas de planturia y cualesquiera otros de la misma naturaleza jurídica, en Asturias, León y Galicia ${ }^{73}$. Sería finalmente en diciembre de 1963, cuando la Ley sobre Compilación del Derecho Civil Especial de Galicia, supondría el remate final de la cuestión al abordar la extinción de foros,

73 Gaceta de Madrid, número 177, 26 de junio de 1926. Pp. 1.802 a 1.804 
subforos, etc.; otorgando un plazo tal que transcurrido el mismo (en total diez años) el forista pierde el gravamen o foro en favor del forero (siempre y cuando no se dé dolo o causa imputable a éste último). La vigencia y proyección actual de la Ley de 1963 supone el final de la cuestión con su previsión para consolidar ambos dominios. Como ejemplo reciente, en 2015 se denegó por parte del registrador de la propiedad número 2 de A Coruña, la inscripción del pleno dominio de una finca, confirmándose en la resolución del 20 de marzo de 2015 emitida a raíz del recurso interpuesto ante la Dirección General de los Registros y del Notariado, que dado el transcurso de aquellos plazos establecidos en la Ley de 1963 sin que ni forero ni forista hubieran hecho uso de la posibilidad que se les otorgaba -y dada también la extinción de la figura de los foros- el dominio directo se había consolidado en el útil del forero ${ }^{74}$

\section{Conclusiones}

El predominio en Galicia de la pequeña propiedad privada rural, con antecedentes medievales comunes a otras tierras peninsulares y europeas, debe su proceso de formación reciente a la deriva que con el liberalismo experimentaron aquellas antiguas tenencias y su desarrollo jurídico y económico posterior. Sus características no se explican por razón directa de antiguas particularidades, sino por efecto de un particular capitalismo, que modificó y amplió el perfil de los propietarios de bienes rurales, contribuyendo de forma tardía a la modernización de la agricultura. La transferencia de tierras desde los señores a los campesinos se articuló en términos relativos al derecho de propiedad, el cumplimiento de los contratos y la libre transmisión de bienes.

Planteado el proceso a partir del abundante debate y producción jurídica entre finales del siglo XIX y comienzos del XX; en el paso desde la propiedad subordinada sometida a renta y derechos forales a otra perfecta con el dominio consolidado, pueden distinguirse por sus características tres fases diferenciadas, durante las cuales y en la medida en que los campesinos acumulan ahorros, van adquiriendo y/o redimiendo bienes y cargas. En la primera, a partir de una situación bloqueada en interinidad permanente (ni unos recuperan ni los otros redimen) desde el último tercio del siglo XVIII, las políticas económicas derivadas de las desamortizaciones consolidarán en la práctica la separación de los dominios útil y real, cambiando solamente la faz de los perceptores de renta. En la segunda, madurado un liberalismo progresista con aspiraciones democráticas y espíritu de justicia so-

74 BOE número 91, 16 de abril de 2015, Pp. 33685 a 33692 
cial, se afrontarán las reformas y se elaborarán proyectos de redención favorables al campesino. Los intereses en juego y los obstáculos legales no permitirán soluciones políticas que zanjen la cuestión. La tercera se define por su impronta jurídica y legalista. Desde las décadas finales del XIX, en un marco económico y político desarrollista y burgués, se articularán desde el derecho civil fórmulas para la consolidación de dominios. La Ley de 1963 será la de punto final. El marco cronológico sirve como referencia temporal para contextualizar lo que se ha considerado como proceso, más que evolución. Este proceso de consolidación de la propiedad (contenciosos incluidos) no es algo absolutamente terminado. Todavía pervive en la actualidad con casos emergentes (como en el ejemplo del año 2015 respecto a un foro de 1868), surgiendo a partir de algún expediente de dominio, transmisión o acto registral, la vieja cuestión de la propiedad gravada con renta foral, pendiente de determinar su pleno propietario. 


\section{Bibliografía}

BARBOSA LORENZO, Carmen (1999): "Manuel Martínez Sueiro. Entre la Historia y la Sociología"; Minius VII; 115-125

BAZ VICENTE, María Jesús (1992): "La conflictividad abolicionista en los estados de Andrade: El pleito de Iñás, Dexo y Serantes”, Anuario Brigantino, 15; 41-54

BUJÁN BUJÁN, Gumersindo (1902): De la propiedad y los foros: estudio jurídico-social, Imprenta de A. Otero, Ourense, (Museo do Pobo Galego, signatura 51)

CABO VILLAVERDE, Miguel y MÍGUEZ MACHO, Antonio (2015): "El caciquismo adaptativo: poder político, movilización social y opinión pública en la Galicia Rural de la Restauración", en www.researchgate.net. Este trabajo se enmarca dentro de los proyectos: «Transformaciones en la agricultura atlántica y evolución dela sociedad rural en el franquismo (1936-1975): cambio tecnológico, medioambiente y dinámica socio -política〉 (HUM2006 - 13499. IP. Lourenzo Fernández Prieto, integrado en el Grupo de Referencia Competitiva: «Historia agraria e política do mundo rural. Séculos XIX e XX». IP: Ramón Villares Paz. Código: 2006/XA024 y «La nacionalización española en Galicia, 1808-1874» (HUM2006-10999. IP Justo Beramendi).

CAMARASA, Marqués de (1909): Los foros. CATECISMO del propietario y forero de propiedad aforada, del dueño y pagador de renta foral desamortizada, del comprador y forero de propiedad aforada civil; Madrid, Establecimiento tipográfico de Fortanet

COLMEIRO PENIDO, Manuel (1843): Memoria sobre el modo más acertado de remediar los males inherentes a la extremada subdivisión de la propiedad territorial de Galicia; Folleto de 68 páginas en $4^{\circ}$. Impreso en Santiago de Compostela, por la Viuda e hijos de Compañel

CORDERO TORRÓN, Xosé (2016): “Los foros en la desamortización. Etapas de Mendizábal y Madoz", en: Revista Galega de Economía; Universidad de Santiago de Compostela; Vol. 25-1

ESTEBAN NAVARRO, Miguel Ángel (1994): “De la esperanza a la frustración, 18681873”, en: TOWNSON, Nigel (Ed.): El republicanismo en España (1830-1977); Madrid, Alianza Universidad; 87-112

GIL VILLANUEVA, Jacobo (1899): Proyecto de Informe acerca del Derecho Foral de Galicia; Imprenta de José María Paredes; Santiago; Minerva-Repositorio institucional de la Universidad de Santiago de Compostela (USC)

GONZÁLEZ-BESADA VIDAL, Basilio (1849): Práctica legal sobre foros y compañias de Galicia. Imprenta de D. Ángel Lema, Vigo (USC-Biblioteca Xeral, signatura DEP ED27 24)

HOBSBAWM, Eric (1998): La era del Imperio, 1875-1914; Crítica, Barcelona

JOVE Y BRAVO, José María Rogelio, del Colegio de Abogados de Oviedo (1883): Los foros. Estudio histórico y doctrinal, bibliográfico y crítico de los foros, en Galicia y Asturias. 
Biblioteca jurídica de autores españoles, Imprenta de la revista de legislación, Madrid. Una reproducción de la obra publicada por Maxtor, Valladolid, 2007

MARTINEZ SUEIRO, Manuel (1912): La cuestión agraria en Galicia. Redención de foros y subforos. Una solución equitativa; Ourense, Imp. Pap. y Enc. LA POPULAR

PAZ NOVOA, Juan Manuel (1872): Los Foros de Galicia; Imprenta de D. Francisco Paz; Ourense; BIBLIOTECA Universidad de Vigo (BUV Bca) Campus de Ourense. Signatura OUR 61005

VALLEJO POUSADA, Rafael (1992): 477-499; "Redención y pervivencia del foro durante la desamortización de Mendizábal", Anuario de historia del derecho español, $\mathrm{n}^{\circ} 62$

VILLARES PAZ, Ramón (1984): 229; "Foros”; en Cañada, S. (Edit.) y Otero Pedrayo, R. (Dir.): Gran Enciclopedia Gallega; impresión de Heraclio Fournier, S.A.; 225-246

VILLARES PAZ, Ramón (1982): La propiedad de la tierra en Galicia, 1500-1936, Madrid, Ed. Siglo veintiuno de España

VILLARES PAZ, Ramón (1985): "Caseiros, rendeiros e foreiros: sobre as formas de cesión da terra en Galicia”, Encrucillada, no 41; 5-17

VINCENTI REGUERA, Eduardo (1886): La ley de redención de censos del señor Montero Ríos y la propiedad foral en Galicia: contestación al señor Marqués de Camarasa; Madrid, Tipografía de Manuel Ginés Hernández, Biblioteca digital de Castilla-León, Ref. 9020 
